\title{
Risk and Response to Biological Catastrophe in Lower Income Countries
}

\author{
Stephen Luby and Ronan Arthur
}

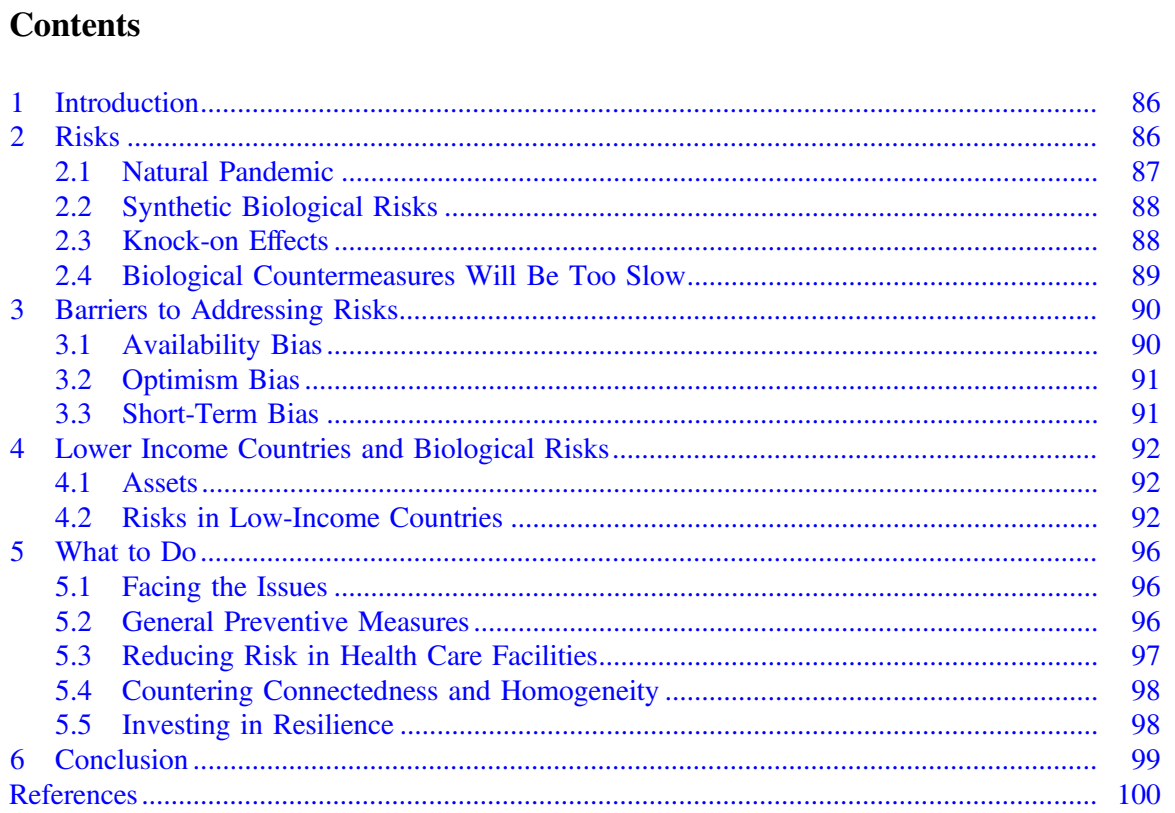

\begin{abstract}
Natural and intentional biological risks threaten human civilization, both through direct human fatality as well as follow-on effects from a collapse of the just-in-time delivery system that provides food, energy and critical supplies to communities globally. Human beings have multiple innate cognitive biases that systematically impair careful consideration of these risks. Residents of low-income countries, especially those who live in rural areas and are less dependent upon
\end{abstract}

S. Luby $(\square) \cdot$ R. Arthur

Stanford University, Y2E2, MC 4205, 473 Via Ortega, Stanford, CA 94305, USA

e-mail: sluby@stanford.edu

Current Topics in Microbiology and Immunology (2019) 424: 85-105

https://doi.org/10.1007/82_2019_162

(C) Springer Nature Switzerland AG 2019

Published Online: 25 May 2019 
global trade, may be the most resilient communities to catastrophic risks, but low-income countries also present a heightened risk for biological catastrophe. Hotspots for the emergence of new zoonotic diseases are predominantly located in low-income countries. Crowded, poorly supplied healthcare facilities in low-income countries provide an optimal environment for new pathogens to transmit to a next host and adapt for more efficient person-to-person transmission. Strategies to address these risks include overcoming our natural biases and recognizing the importance of these risks, avoiding an over-reliance on developing specific biological countermeasures, developing generalized social and behavioral responses and investing in resilience.

\section{Introduction}

The probability of a catastrophic biological disaster that would undermine future human thriving is difficult to estimate with precision but is sufficiently plausible to merit serious consideration. Such an event would not be unprecedented as humans have suffered from devastating infectious disease epidemics before. The initial stages of the European Black Death (1346-1353) killed an estimated $60 \%$ of the population of Europe (Benedictow 2004). Up to $90 \%$ of the indigenous population in the Americas are estimated to have died in successive waves of smallpox, measles, plague and typhus outbreaks introduced by European settlers (Hays 2005).

Although scientific understanding of infectious disease and medical countermeasures including antibiotics, vaccines and clinical management have advanced considerably since these calamities, the probability of such a catastrophe may be higher now than ever. The twenty-first-century earth is home to more people, who are more connected with each other, and who are more exposed to novel pathogens and at increasing risk of exposure to synthetic pathogens.

Much of the consideration of how to manage contemporary global biological risks has focused on actions within high-income countries. However, in 2016, 84\% of the world's population lived outside of high-income countries (World Bank 2018). Lower income countries carry the majority of the current global burden of infectious disease and are the most likely locations for novel disease spillover from animal reservoirs and adaptation to human transmission. These countries should therefore be a primary focus of efforts to prevent and respond to the next biological catastrophe.

\section{Risks}

There are many plausible scenarios of biologically engendered human catastrophe. We mention a few here to illustrate some possibilities and so frame considerations in lower income countries. 


\subsection{Natural Pandemic}

A new pathogen could emerge that is readily transmissible, for example through the air, and results in the destruction of ovarian or testicular parenchyma or fallopian tube scarring. Within a few months, the capacity for human reproduction could be so reduced that the human future would be catastrophically diminished. An alternative scenario would be the unrecognized introduction of a prion or a biological toxin with a long latency into the global food supply in a commodity such as one of the staple grains that is widely distributed and consumed. If, like prion-mediated disease, the agent had a multi-year latent period, billions of people could be exposed before the problem was ever recognized or linked to a specific food. Currently, an estimated $23 \%$ of the food produced for human consumption is traded internationally (D'Odorico et al. 2014). This proportion has been steadily increasing and, due to shortage of land and water in many food importing countries with growing populations, as many as 5.2 billion people in 2050 are projected to be dependent on food grown outside of their country (Fader et al. 2013). The increased globalization of the food supply (Suweis et al. 2015) means that a long latency biological toxin that contaminates the food supply could generate a global catastrophe. Moreover, the increased dependency upon imported food staples means that large populations are at risk of emerging plant pathogens that might quickly undermine the availability of a key crop (Evans and Waller 2010; Strange and Scott 2005).

A novel human pathogen could also emerge naturally from an animal reservoir, spillover into humans and adapt to human-to-human transmission. For a natural pathogen to have highly catastrophic consequences, it must have two characteristics - it must be both highly transmissible and cause high mortality or crippling morbidity. Often pathogens have one of these two characteristics but not both. Influenza, for example, is highly transmissible and can efficiently spread around the globe, but typically has low mortality $(<0.05 \%)$ (Kelly et al. 2011; Nishiura 2010). Even if a novel strain of influenza approached the case fatality rate observed in the 1918 pandemic of 1-3\% (Frost 1920), the vast majority of humanity would survive. Although such an outbreak would present a terrifying global shock, it would be less likely to alter the human future compared with outbreaks that killed more of the population, for example, the Black Death in Europe.

By contrast, there are diseases that have high mortality, but limited transmission. Nipah virus, for example, is a virus whose wildlife reservoir is bats of the genus Pteropus (Halpin et al. 2011). The bats live across South and Southeast Asia, south into Australia and as far west as Madagascar (Nowak 1994). Although the virus causes no disease in bats (Middleton et al. 2007), when humans become infected, 40-80\% die (Chua 2003; Luby et al. 2009). Person-to-person Nipah transmission occurs but is not efficient. On average, each infected patient transmits Nipah to $<1$ other person (Luby et al. 2009). Thus, person-to-person Nipah outbreaks generate non-sustained stuttering chains of transmission. It is a deadly disease for those infected, but the number of infected are few. However, if a virus like Nipah, that is a 
virus that has a high fatality rate and already has demonstrated competency for person-to-person transmission, were to develop an enhanced capacity for person-to-person transmission, it could present a global catastrophic biological risk.

\subsection{Synthetic Biological Risks}

Other scenarios include the intentional synthesis and release of a novel pathogen capable of efficient transmission and high mortality. To date, biological weapons have not been the weapons of choice in most violent conflicts; however, recent developments increase future risk. CRISPR and other techniques of genome editing and associated developments in synthetic biology make it easier each year to genetically modify organisms, including human pathogens. Technology continues its exponential development becoming increasingly portable, increasingly powerful and less expensive. This expansion of biological knowledge and tools means that the capacity to manipulate organisms will become progressively easier to implement and available to more and more people. Today, many graduate students in the life sciences at leading universities can modify organisms and so change their function or develop novel synthetic organisms. As the techniques become more refined, these capacities will be deployed in high school science projects and available to tens of thousands of people who can learn the essentials with a focused review of information available on the internet.

With the capacity for constructing synthetic pathogens increasingly available, initiating an intentional synthetic pandemic would not require massive funding and a political state with legions of collaborators but could be deployed by moderately sized terrorist cells or a disgruntled individual. Biological weapons also offer the opportunity for preserving some populations through preemptive immunization while leaving the broader population susceptible, strategy that may appeal to groups with fanatical views of religious, ideological, ethnic or cultural purity.

The increasing ease of gene editing and synthetic biology means that more groups, many with little background in lab safety or appreciation of potential consequences will be editing and creating new organisms. The sheer number of people engaged increases the risk of the unintentional release of a dangerous agent. The year on year increase in both the potency and the availability of the tools for synthetic biology progressively increases this risk.

\subsection{Knock-on Effects}

Biological catastrophe presents both immediate threats from the direct loss of human lives, as well as knock-on effects from collapsing systems. Large cities, especially those in low-income countries are ill-prepared for major disruptions. The 
exponential growth of cities in the global south is unprecedented. The populations of Mumbai, Dhaka, Delhi, Kinshasa, Kolkata, Lagos and Karachi each had populations < 10 million people in 1990 but are now each projected to exceed 30 million people by 2050 (Hoornweg and Pope 2017). Throughout the global south, municipal governments exert limited influence on planning (Kombe 2005; Zebardast 2006; Narae 2014). Instead, these massive expansions are driven by real estate interests and firm level and household level economic decisions. Essential services to the population of the cities including water, electricity and transport are characteristically marginal, especially to residents of the poorest communities in the cities (Sverdlik 2011; Habitat 2015). The poor are already paying on average 10100 times more per liter of water than the wealthy (McIntosh 2003; Segerfeldt 2005). Many children living in poor urban communities face chronic malnutrition from poor diets (Fotso 2006). These sprawling cities have little reserve capacity to draw upon in the event of a catastrophe.

\subsection{Biological Countermeasures Will Be Too Slow}

If transmission were efficient enough to infect most people in the world, it is unlikely that biological countermeasures would be developed soon enough to prevent catastrophic impact. When a new strain of influenza H1N1 was identified in Mexico in April 2009 and was thought to represent a major pandemic risk, vaccine development was prioritized. The first vaccine to protect against this new strain was licensed five months later. By December, eight months after identification of the new pathogen, a total of 534 million doses of vaccine had been manufactured (Partridge and Kieny 2010) that after the weeks or months required to implement vaccination campaigns would be sufficient vaccine to immunize $8 \%$ of the world population. By contrast, by December 2009 human cases of H1N1 were already confirmed in 208 countries, overseas territories and communities (Girard et al. 2010). Based on extrapolation of observed transmission patterns, between 25 and $39 \%$ of the world's population was infected within the first year (Girard et al. 2010). Thus, even for influenza, a pathogen with well-known pandemic potential and a well-defined process used annually to develop vaccines for global distribution, pathogen transmission proceeded much faster than the development of a specific effective biological countermeasure.

With a genuinely novel pathogen, the development of effective countermeasures would be considerably delayed. Unless the developments, approval and distribution of specific biological countermeasures could be markedly reduced from the historical norm of months to years to what is currently an unimaginably short time of days to weeks, then we can expect a genuinely novel pandemic that is readily transmissible by respiratory contact to spread globally before any effective biological countermeasure will be in place.

The panic associated with an evolving catastrophe is also likely to impair consideration of a full range of alternative actions and careful decision-making 
(Baradell and Klein 1993; Holsti 1972; Keinan 1987; Starcke et al. 2008). Rash decisions increase the risk of biological countermeasures that, themselves, may worsen the impact of the event. Approaches that deploy synthetic counter agents including those that use gene drive technologies intended to change the genetic structure of extant populations and their progeny are particularly concerning.

\section{Barriers to Addressing Risks}

Serious consideration of catastrophic biological risks and sound planning for prevention is compromised by multiple cognitive barriers shared by scholars, politicians and the general population.

\subsection{Availability Bias}

Human risk perception is heavily biased toward personal experience and emotionally vivid images that are easy to recall. For example, descriptions of violent death are common in news reports and mass culture and their very vividness brings them to mind when considering risks. As a result, the general population substantially overestimates the risk of violent death and underestimates the risk of death from diabetes or heart disease (Combs and Slovic 1979). This tendency to equate probability with the ease of bringing a particular scenario to mind, termed availability bias, is common and undermines sound judgment including assessing the risk of unprecedented biological catastrophe (Tversky and Kahneman 1973).

Accurately forecasting risk is profoundly difficult. We do not know what the future will bring, yet in many domains of personal life and policy planning, we have substantial prior experience that helps us predict and so plan for an uncertain future. A farmer does not know that the market for wheat in the coming season will be sufficient to recover his investment, nor can he be sure that the temperature and rainfall patterns will support a good yield. However, he can draw upon his prior experience to project likely scenarios for the upcoming season and so decide on prudent investments. People are generally able to plan for and mitigate risks of high-impact, low-probability events so long as the risk is well understood. Flood and fire insurance, for example, is commonly purchased despite floods and fires being unlikely. Media reports of floods and fires and occasional personal experience presents a sufficiently salient scenario to generate protective action (Browne and Hoyt 2000).

Forecasting the probability and timing of an unprecedented global biological catastrophe are more difficult, because our available experience is largely uninformative. The common approach to human decision-making conflicts with a nuanced consideration of uncertainty. Humans prefer simple narratives (Taleb 2007), but risks of biological catastrophe arise from the interaction of complex 
social, ecological and transmission systems (Arthur et al. 2017), and this complexity renders prediction impossible (Moore 1990). Even professionals who make forecasts are unable to overcome these inherent epistemological difficulties. Indeed, professional forecasts of complex phenomena, for example, the performance of individual stocks in the stock market, the direction of the global economy, the outcome of sporting matches or of political events are notoriously unreliable (Torngren and Montgomery 2004; Andersson et al. 2005; Tetlock 2017). In any given year, a global biological catastrophe is a low-probability occurrence and so, based on a lifetime of experience, it seems fine to ignore, but the cumulative risk and catastrophic consequences suggest this understandable approach is imprudent.

\subsection{Optimism Bias}

Human decision-making is also prone to an optimistic bias. Although an optimistic disposition contributes to effective leadership, an optimistic bias also explains why most new businesses fail (Cooper et al. 1988; Hayward et al. 2006). When the risk of global catastrophe is raised in conversation, a common response is quick dismissal of the line of conversation with simplistic notions of wishful thinking that "humanity will avoid this" or "we will work something out" or "God has a plan for us." All of these responses reflect the discomfort of looking squarely at these credible but horrifying scenarios as they can often feel too big to grapple with, and their uncertain and unprecedented nature undermines their plausibility.

It is more psychologically comfortable to ignore terrifying risks than to consider them seriously. A historical example of a combination of availability and optimistic bias contributing to ignoring a catastrophic risk is the flood in Johnstown, Pennsylvania on May 31, 1889. An earthen dam was built $23 \mathrm{~km}$ up river and although there were expressed concerns about the structural stability of the dam and a recognition that if the dam broke, it could be catastrophic for the residents of Johnstown, residents reasoned that since it had not failed in the 50 years before 1889, catastrophic failure was unlikely, indeed, unimaginable (McCullough 2007). This failure to imagine, and so take seriously this risk, resulted in the largest loss of civilian life in a single event in the USA up to that time.

\subsection{Short-Term Bias}

Political decision-makers are rewarded for taking actions to address immediate salient concerns at the expense of investment that will yield longer term, though less immediately attributable benefits. This short-term bias in political decision-making leads to overinvestment in capital projects with underinvestment in operation and maintenance (Devarajan et al. 1996), inattention to long term progressively worsening fiscal problems, for example, running growing fiscal deficits at times of 
relative economic prosperity in the context of a progressively aging population and underinvestment in early childhood education and environmental preservation (Aidt and Dutta 2007; Nixon 2011). Politicians are rarely rewarded for preventing an adverse outcome. Because the outcome does not occur, it neither becomes salient nor is the political leaders credited. By contrast, political leaders who react to short-term perceptions of risk are rewarded by voters who perceive them as active and responsive (Aidt and Dutta 2007).

\section{Lower Income Countries and Biological Risks}

\subsection{Assets}

Lower income countries may face the risk of catastrophic biological risks differently than more stable, wealthier countries. Compared with residents of high-income countries, more households in low-income countries have recent experience with child death, early adult death, extreme deprivation, political instability, social instability and armed conflict (Stewart et al. 2002; Østby 2008). The breadth and salience of tragedy mean that residents of poor countries may be less prone to optimism bias and availability bias regarding potential adverse future scenarios compared with higher income countries.

Residents of low-income countries, especially those who reside in rural areas, also have less dependence on centralized infrastructure than communities in high-income countries. Engineered water, energy and transportation infrastructure does not reach large portions of low-income country populations. This means that the livelihood of these populations is less dependent on centralized systems that risk complete failure during a disaster (Perrow 1999).

Subsistence farmers living in small remote mountain communities are perhaps the human populations most resistant to catastrophic biological risks. They are less dependent on the global economic and transport system to support their livelihood. Their geographical isolation also limits their contact with others who can spread communicable disease. These remote largely self-sufficient communities may represent humanity's future in the aftermath of a global biological catastrophe.

\subsection{Risks in Low-Income Countries}

Areas at the highest risk for the emergence and spillover of novel pathogens, or disease "hotspots," are disproportionately located in low-income countries (Morse et al. 2012). Infectious pathogens that have caused the majority of human mortality through history originated as pathogens in other animals. Examples of such zoonotic 
pathogens include human immunodeficiency virus, tuberculosis, measles, smallpox and plague (Wolfe et al. 2007). In rural communities in low-income countries, people live in close contact both with their domestic animals (Sultana et al. 2012; Gondwe and Wollny 2007; Nahar et al. 2013) and with wildlife (Friant et al. 2015; Brashares et al. 2011). Population expansion in low-income countries is increasing exposure to wild animals and their pathogens with zoonotic potential (Weiss and McMichael 2004). The biological safety measures that are in place in high-income countries to reduce the risk of zoonotic spillover to industrial agricultural producers are not affordable to low-income agricultural producers (Rimi et al. 2017). Educational efforts designed to encourage low-income producers to expend their time and money to reduce pandemic biosecurity risks in their animal husbandry practices have generally failed (Paul et al. 2013; Manabe et al. 2012; Barennes et al. 2010; Rimi et al. 2016). For a low-income producer who is striving to provide a subsistence lifestyle to his/her family, time is preferably invested into activities that provide immediate improvements to family likelihood, rather than into abstract considerations regarding mitigation of global pandemic risk (Sultana et al. 2012).

The condition of healthcare facilities in low-income countries also contributes to global pandemic risk. Hospitals in low-income countries are remarkably crowded. Structured observations in three hospitals in Bangladesh counted a mean of 3.7 people per $10 \mathrm{~m}$ (Hays 2005) of floor space who generated a median of 4.9 uncovered coughs or sneezes per hour (Rimi et al. 2014). The crowding of susceptible people within these overwhelmed institutions provides opportunities for the spread of a new pathogen. A dangerous novel pathogen might otherwise never achieve sustained transmission because of the exhaustion of susceptible hosts, but in an environment enriched with densely situated highly susceptible hosts, the pathogen has more opportunity to transmit and to spend more time in human hosts, that is an environment that exerts selective pressure for traits that improve the efficiency of person-to-person transmission (Antia et al. 2003).

Healthcare facilities in low-income countries routinely lack access to running water, soap, gloves, masks, waste management and institutional practices that could potentially interrupt transmission of dangerous pathogens (World Health Organization 2015; Ansa et al. 2002; Engelbrecht et al. 2015; Rajakaruna et al. 2017). Although there are substantive financial barriers to improving the situation, poor accountability and the structure of incentives within health care institutions in low-income countries, especially public health care institutions, represent an even more formidable barrier (Lewis and Gelander 2009). In most low-income countries, government salaries are low compared to employment in the private or NGO sector (McCoy et al. 2008). Officials in government health care institutions commonly use their positions to extract funds from patients (Roenen et al. 1997; Andaleeb 1998; Thappa and Gupta 2014; Nordberg 2008). Budgets for supplies and disposables in these institutions often never reach the facilities (Nordberg 2008). Supplies that do come to hospitals are routinely commandeered by hospital personnel and transferred to their own private clinics or sold on the open market (Lewis and Gelander 
2009; Killingsworth et al. 1999; Gray-Molina et al. 2001; Ferrinho et al. 2004). Government health care workers are frequently absent (Lewis and Gelander 2009; García-Prado and Chawla 2006; Belita et al. 2013; Chaudhury et al. 2006).

Although the World Health Organization has specified standards for reducing infection in low-income countries institutions (World Health Organization 2004), the standards are so at odds with available budgets and the incentives that drive behaviors in health care institutions in low resource settings (Lewis and Gelander 2009; Killingsworth et al. 1999; Hadley et al. 1982; Zaman 1982), that outside of externally funded time-limited demonstration projects, these standards have not been adopted. Health research funders have demonstrated little appetite to support research to develop strategies to reduce the risk of the exponential acceleration of transmission of novel agents in low-income country hospitals, despite these settings being important sites of person-to-person transmission for Ebola (Shears and O’Dempsey 2015), Nipah (Chadha et al. 2006; Ching et al. 2015), Smallpox (Mack 1972), Crimean-Congo hemorrhagic fever (Aradaib et al. 2010; Parlak et al. 2015) and likely novel agents that risk a global catastrophe.

High-income countries that develop biological countermeasures in response to a novel catastrophic biological risk are likely to prioritize protecting their own population rather than residents of low-income countries, even if those low-income populations are at higher risk. The deployment of pandemic H1N1 vaccine is instructive. Vaccine was only made available to low-income countries, once high-income countries had sufficient supply to vaccinate their own population (Fidler 2010). The consequence of this prioritization is that the scale of a catastrophe is likely to be larger and more threatening globally.

Low-income countries are urbanizing at unprecedented scales. The large and growing human population has appropriated an unprecedented proportion of the biological output of the planet for food production (Krausmann et al. 2013). Over half of the world's population lives in cities and this proportion is projected to increase (United Nations 2016). Nearly, all of the food to support these urban residents is grown outside of cities (Zezza and Tasciotti 2010). This food production requires ongoing biological, agricultural and economic activity. Indeed, the global stocks of grain are only sufficient to meet $20 \%$ of annual human food consumption (Lilliston and Ranallo 2012). Thus, a functioning transportation system and system of economic exchange are essential to avoid food shortages, panic and widespread starvation. If an infectious pathogen that is transmitted from person to person generated a high risk of human mortality, in addition to systematic impairment from disabled workers, fear magnified by the mass media (Altheide 1997) could undermine the basic trust and social cohesion that undergirds movements of goods and economic exchange. The enormous needs for foodstuffs in urban communities would rapidly exhaust existing stores, that if not promptly resupplied, would generate further fear, hunger, malnutrition, attendant infection disease and social disruption. Indeed, even if the precipitating epidemic affected less than $1 \%$ of the population, it's follow-on impacts risk catastrophe. 
The marked increase in human population density and the growth in transportation networks of roads, container ships and airways linking the global population presents more rapid and robust pathways for infectious pathogens than humankind has previously faced (Ahmed et al. 2013; Kaluza et al. 2010; Tatem et al. 2006). Previously, with lower population densities, a new pathogen capable of causing a global pandemic may never have escaped the small human community where it first appeared. For example, consider Nipah virus that was listed in 2017 by the World Health Organization as a priority disease for research and development because of its potential to generate a public health emergency (World Health Organization 2017). The primary pathway of transmission of Nipah virus from Pteropus bats to humans in Bangladesh is contamination of date palm sap during harvest by Pteropus bats that are shedding virus, with people in rural communities drinking the harvested raw sap a few hours later (Luby et al. 2006; Hegde et al. 2016). Most people who are infected with Nipah virus die (Hossain et al. 2008). Some pass the infection on to other people (Chadha et al. 2006; Gurley et al. 2007). Nipah has not caused a pandemic because it does not transmit efficiently from person to person, though it remains a pandemic concern because of the risk that a new strain of Nipah virus may emerge that is more efficiently transmitted from person to person (Luby 2013). Although Nipah virus was first recognized in 1999 (Hsu et al. 2004), the wide distribution of this family of viruses among Pteropus bats (Hsu et al. 2004; Chua et al. 1999; Field et al. 2011; Wacharapluesadee et al. 2010) and related species (Drexler et al. 2009) and the lack of symptoms in infected bats (Halpin et al. 2011; Middleton et al. 2007) suggests that Nipah virus co-evolved with Pteropus bats and has been shed by these bats for millennia. People lived in the area of modern day Bangladesh and have harvested date palm sap for centuries (Blattner 1978). However, if a strain of Nipah virus that was efficiently transmitted from person to person spilled over from bats to residents of a remote village in the nineteenth century, even if most of the village residents became infected and died, because of difficult transportation between villages and so infrequent interpersonal contact between human settlements, the chain of transmission would likely stop. In the twenty-first century, by contrast, the progressive increase in human population density increases the probability that a potentially pandemic pathogen originating in one community will encounter a sufficiently dense network of human connectivity to support ongoing transmission.

Lower income countries also present some special risks for development of synthetic pathogens or gain of function of natural pathogens. Scientists in lower income countries generally have less secure professional tenure and less access to research funding. Groups who are willing to pay for synthetic biology skills are likely to find an available under-employed labor market who would be able to exploit the increasingly available and easy to use synthetic biology tools. Laboratories in low-income countries also tend to have less strict licensing requirements. In these contexts, engagement in lucrative pathogen development work is less likely to be counterbalanced by institutional forces striving to preserve the institutional reputation and commitment to internationally recognized highly valued socially productive research. 


\section{What to Do}

\subsection{Facing the Issues}

Both low resourced communities and the broader global community can take several steps to protect against the formidable risk of biological catastrophes. First, universities, researchers, journalists and funders should rank analyzing and defending against global catastrophic biological risks as important topics for serious consideration and so attract the creative, analytic and problem-solving skills of students, researchers, planners and implementers. Increasing the priority of such work will require addressing a number of psychological barriers including optimism and availability bias, as well as the reluctance to invest in interventional social science research. Vivid scenarios depicting the potential pathways and consequences of biological catastrophe may be helpful in overcoming these biases (Combs and Slovic 1979; Slovic et al. 2004; Gong et al. 2017; Trutnevyte et al. 2016). Identifying and addressing key research questions can both improve our understanding of risks and provide guidance on optimal actions in the face of these risks. Such a study should include how political economy incentives contribute to the failure to address these risks. These include the lack of attention to these concerns in the general public and so to politicians, the short-term focus of the majority of political action and the substantial institutional reorientation required to prioritize a prevention/resilience focus. Although these risks are biological, engaging them requires transcending the biological paradigm.

\subsection{General Preventive Measures}

Because of the difficulty in knowing which specific biological catastrophe is imminent and the long lead time required to develop risk-specific medical countermeasures, even substantial investment in developing such countermeasures is unlikely to produce a custom solution available for the specific novel risk that develops. By contrast, there are a number of non-medical countermeasures that could be quickly deployed and may be effective against a wide range of biological threats. For example, increasing the frequency of hand washing with soap or alcohol gel can reduce the transmission of a variety of infectious agents including influenza (Talaat et al. 2011), Nipah (Gurley et al. 2007) and SARS (Fung and Cairncross 2006). Prior research has identified several techniques that by creating an environment where it is easy to wash hands, that is where soap and water or alcohol gel is conveniently available and behavior change messaging is iteratively developed with the target population and responds to their perspectives and values, then intensive interpersonal communication markedly improves hand washing practices (Briscoe and Aboud 1982; Stanton and Clemens 1987; Langford et al. 2011). 
There is much less evidence, however, about how to improve hand washing targeting tens of millions of people using mass media (Galiani et al. 2012). During previous high profile outbreaks, rapidly deployed recommendations to increase hand washing frequency measurably improved hand washing behavior (Lau et al. 2003; Rubin et al. 2009; Agüero and Beleche 2017). Additional research to further develop the reach and effectiveness of such rapidly deployable mass interventions could provide a crucial tool to reduce the impact of a catastrophic outbreak.

Other approaches including travel bans, school closures and quarantines have also been deployed during infectious disease outbreaks. The evidence that these approaches reduce infection transmission has been variable. Although mathematical models suggest that travel bans could delay the introduction of an epidemic (Brownstein et al. 2006; Epstein et al. 2007), in practice travel bans have targeted places where the press has identified a novel threat, but infectious disease transmission generally outpaces our capacity to detect it. In addition, interrupting travel threatens the global trade system that supplies critical food, medicine and energy to communities globally. Similarly, most studies find that school closures moderately reduce influenza transmission (Cauchemez et al. 2008; Jackson et al. 2013), but the effect is heterogeneous and may or may not apply to a novel biological threat. It would be helpful to further develop our scientific understanding of what measures can be taken that are effective in reducing infectious disease transmission. These approaches can be rigorously evaluated and their impact assessed in less than catastrophic outbreaks to guide the development of sound, rapid implementable responses to larger crises.

\subsection{Reducing Risk in Health Care Facilities}

Developing and evaluating sustainable strategies to reduce the transmission risk of dangerous agents in healthcare facilities in low-income countries is an under-explored area of research that, with attention, is likely to identify strategies to reduce risk. Political scientists have developed thoughtful conceptual models of impaired governance and corruption in weak states (Migdal 1988; Börzel and Risse 2010). Advocates for health care system reform have specifically analyzed governance barriers and suggested strategies for addressing these barriers (Lewis and Gelander 2009). There is an increasing empirical literature of intervention trials to improve governance generally (Humphreys and Weinstein 2009) as well as improving governance in the health sector (Gaitonde et al. 2016). Because poor governance and corruption are characteristically tied to long-standing historical developments and political and social tensions (Migdal 1988; Coovadia et al. 2009) they are unlikely to be resolved with a simple quick fix. Interventions to reduce pathogen transmission in these low-income weak state contexts are likely to look quite different from interventions in high-income countries that function within a different model for staff compensation, different institutional norms and regulatory agencies capable of enforcement. Indeed, we should expect approaches that work 
fine in a high resourced context would almost certainly fail in this quite different context. A research effort that explores the heterogeneity of practices and capacity for prevention of healthcare-associated infection in low resource settings and identifies the specific dimensions associated with increased and decreased risk could identify insights and approaches that would inform a more realistic approach to interventions to reduce risk. Generating useful new knowledge and approaches in reducing healthcare-associated infections in low-income health care facilities will require both funders and researchers to think beyond the paradigm of biomedical science, to an approach that is informed by political science, health system and infection control literature and rooted in empirical studies in these contexts.

\subsection{Countering Connectedness and Homogeneity}

We should respect the value of remoteness including policies to intentionally leave some communities only remotely connected and so largely independent from the broader global economic and social system. Although development policy usually assumes that connection with the broader world will bring benefit, both these communities and the human future might be better served by a less complete connection. Remote mountain communities may be the best locations to preserve separation. Similarly, a heterogeneous food supply would be more resilient in the face of biological catastrophe in contrast to a globalized monoculture where each individual crop is cultivated in a setting that optimizes yields, but also requires an uninterrupted just-in-time delivery system to provide calories and essential nutrients to populations globally. Diverse local foods would provide some resilience against interruptions in international trade that could accompany global biological catastrophe. A wider variety of cultivars would make the global food supply less susceptible to a devastating plant pathogen. Policies that support urban agriculture can further contribute to resilience (De Bon et al. 2010).

\subsection{Investing in Resilience}

The liberal economic system rewards improvements in efficiency. Nassim Taleb asserts that if an economist was in charge of designing the human body, he would include only one kidney (Taleb 2007). What is the use of expending resources on a second kidney that most people would never need? Natural selection, however, has favored both efficiency and resilience. To protect against global catastrophic biological threats, societies should invest in resilience. A resilience framing accepts that extreme events will occur and prioritizes strategies to limit the loss and prevent spiraling knock-on effects. Resilience planning should occur at multiple levels and take several forms. Strategies to provide essential food, water and power in the event of severe disruption lasting weeks or months should be a standard 
consideration of city authorities. Distributed systems that provide power, water and food are less susceptible to cataclysmic point failure than completely centralized systems (Perrow 1999). Within growing populations especially in informal settlements in low-income country cities and with progressive per capita availability of freshwater, decentralized approaches that leverage local resources to provide safe drinking water and reduce environmental contamination are being deployed at several sites (Massoud et al. 2009). Urban gardens and urban farms can improve the resilience of neighborhoods and cities. Such distributed systems are increasingly efficient and are being adopted in many contexts (Guerrero et al. 2010).

Households can also be encouraged to keep several weeks or even months' supply of nonperishable food in their homes. The more households that are not completely dependent on external food supplies in the initial days or weeks of a cataclysm, the more time and human capital are available to address the crisis and repair systems.

\section{Conclusion}

Although the probability of any particular biological risk is indeterminate, the number of plausible scenarios, the growing size and connection of the human population and the potential for catastrophic consequences suggests that society should devote serious attention and resources to these risks.

Broad engagement with these risks requires awareness of the widespread biases that undermine advancing this work. In addition to the cognitive biases toward availability and optimism that undermines sound risk analysis, funders, researchers and decision-makers also need to avoid a bias toward simplicity, both in understanding these systematic risks and in assuming biological magic bullets will solve these complex problems. Much of the consequences of biological catastrophe are likely to result from ruptures in productive social interaction. Thus, some of the most effective prevention likely rests within optimizing human behavior and supporting the social sphere.

Non-wealthy countries represent both the highest risk of catastrophic biological perturbations as well as the locations where efforts at prevention can yield the greatest benefit. Since all of humanity shares the biome, retreating behind wealthy walls within high-income neighborhoods or within high-income countries will not provide robust protection. This is a genuinely global problem that calls for a global collaborative effort to reduce risk.

The other side of the bias toward optimism, that we need not attend to these problems, is a bias toward pessimism, the belief that we cannot do anything to prevent upcoming cataclysms, so it is not worth the effort to attempt to counter these risks. Both of these unproductive framings should be addressed. The entire fields of risk assessment, public health and global security planning assume that we can address the difficult, seemingly intractable problem. Smallpox used to kill millions each year (Hays 2005). A focused effort to understand and counter this risk 
eradicated smallpox (Fenner et al. 1988). Chlorofluorocarbons were depleting the earth's atmospheric ozone and the benefit this provides in protecting the earth against ultraviolet light (Molina and Rowland 1974). Scientific understanding of the risk and collective human effort produced less damaging alternatives to chlorofluorocarbons. An international treaty to control the use of chlorofluorocarbons resulted in the near elimination of the use of chlorofluorocarbons and progressive recovery in the ozone layer (Newman et al. 2009). In short, human history has demonstrated that apparently overwhelming risks can be successfully engaged and reversed. Similarly, the potential catastrophic risks considered here are not insoluble. They can be addressed through research, careful consideration of broad social factors, informed public dialog and thoughtful intervention.

\section{References}

Agüero JM, Beleche T (2017) Health shocks and their long-lasting impact on health behaviors: Evidence from the 2009 H1N1 pandemic in Mexico. J Health Econ 54:40-55

Ahmed SE, Souza CM, Riberio J, Ewers RM (2013) Temporal patterns of road network development in the Brazilian Amazon. Reg Environ Change 13:927-937

Aidt TS, Dutta J (2007) Policy myopia and economic growth. Eur J Polit Econ 23:734-753

Altheide DL (1997) The news media, the problem frame, and the production of fear. Sociol Q 38:647-668

Andaleeb SS (1998) Choice and evaluation of hospitals in Bangladesh: insights from patients and policy implications. J Health Epidemiol Dev Ctries 1:19-28

Andersson P, Edman J, Ekman M (2005) Predicting the World Cup 2002 in soccer: performance and confidence of experts and non-experts. Int J Forecast 21:565-576

Ansa VO, Udoma EJ, Umoh MS, Anah MU (2002) Occupational risk of infection by human immunodeficiency and hepatitis B viruses among health workers in south-eastern Nigeria. East Afr Med J 79:254-256

Antia R, Regoes RR, Koella JC, Bergstrom CT (2003) The role of evolution in the emergence of infectious diseases. Nature 426:658-661

Aradaib IE, Erickson BR, Mustafa ME et al (2010) Nosocomial outbreak of Crimean-Congo hemorrhagic fever, Sudan. Emerg Infect Dis 16:837-839

Arthur RF, Gurley ES, Salje H, Bloomfield LS, Jones JH (2017) Contact structure, mobility, environmental impact and behaviour: the importance of social forces to infectious disease dynamics and disease ecology. Philos Trans R Soc Lond Ser B, Biol Sci 372

Baradell JG, Klein K (1993) Relationship of life stress and body consciousness to hypervigilant decision making. J Pers Soc Psychol 64:267

Barennes H, Harimanana AN, Lorvongseng S, Ongkhammy S, Chu C (2010) Paradoxical risk perception and behaviours related to Avian Flu outbreak and education campaign, Laos. BMC Infect Dis 10:294

Belita A, Mbindyo P, English M (2013) Absenteeism amongst health workers-developing a typology to support empiric work in low-income countries and characterizing reported associations. Hum Resour Health 11:34

Benedictow OJ (2004) The Black Death, 1346-1353: the complete history: Boydell \& Brewer

Blattner EB (1978) The palms of British India and Ceylon. Experts Book Agency, Dehli

Börzel TA, Risse T (2010) Governance without a state: can it work? Regul Gov 4:113-134

Brashares JS, Golden CD, Weinbaum KZ, Barrett CB, Okello GV (2011) Economic and geographic drivers of wildlife consumption in rural Africa. Proc Natl Acad Sci 108:13931-13936 
Briscoe C, Aboud F (1982) Behaviour change communication targeting four health behaviours in developing countries: a review of change techniques. Soc Sci Med 2012(75):612-621

Browne MJ, Hoyt RE (2000) The demand for flood insurance: empirical evidence. J Risk Uncertain 20:291-306

Brownstein JS, Wolfe CJ, Mandl KD (2006) Empirical evidence for the effect of airline travel on inter-regional influenza spread in the United States. PLoS Med 3:e401

Cauchemez S, Valleron AJ, Boëlle P, Flahault A, Ferguson NM (2008) Estimating the impact of school closure on influenza transmission from Sentinel data. Nature 452:750

Chadha MS, Comer JA, Lowe L et al (2006) Nipah virus-associated encephalitis outbreak, Siliguri, India. Emerg Infect Dis 12:235-240

Chaudhury N, Hammer J, Kremer M, Muralidharan K, Rogers FH (2006) Missing in action: teacher and health worker absence in developing countries. J Econ Perspect 20:91-116

Ching PKG, de los Reyes CV, Sucaldito MN, Tayag E, Columna-Vingno AB, Malbas FF et al (2015) Outbreak of henipavirus infection, Philippines, 2014. Emerg Infect Dis

Chua KB (2003) Nipah virus outbreak in Malaysia. J Clin Virol 26:265-275

Chua KB, Goh KJ, Wong KT et al (1999) Fatal encephalitis due to Nipah virus among pig-farmers in Malaysia. Lancet 354:1257-1259

Combs B, Slovic P (1979) Newspaper coverage of causes of death. J Q 56:837-849

Cooper AC, Woo CY, Dunkelberg WC (1988) Entrepreneurs' perceived chances for success. J Bus Ventur 3:97-108

Coovadia H, Jewkes R, Barron P, Sanders D, McIntyre D (2009) The health and health system of South Africa: historical roots of current public health challenges. Lancet 374:817-834

De Bon H, Parrot L, Moustier P (2010) Sustainable urban agriculture in developing countries. A review. Agron Sustain Dev 30:21-32

Devarajan S, Swaroop V, Zou H (1996) The composition of public expenditure and economic growth. J Monet Econ 37:313-344

D'Odorico P, Carr JA, Laio F, Ridolfi L, Vandoni S (2014) Feeding humanity through global food trade. Earth's Future 2:458-469

Drexler JF, Corman VM, Gloza-Rausch F et al (2009) Henipavirus RNA in African bats. PLoS ONE 4:e6367

Engelbrecht MC, Van Rensburg AJ, Nophale LE et al (2015) Tuberculosis and blood-borne infectious diseases: workplace conditions and practices of healthcare workers at three public hospitals in the Free State Southern African. J Infect Dis 30:23-28

Epstein JM, Goedecke DM, Yu F, Morris RJ, Wagener DK, Bobashev GV (2007) Controlling pandemic flu: the value of international air travel restrictions. PLoS ONE 2:e401

Evans HC, Waller JM (2010) Globalisation and the threat to biosecurity. In: Strange RN, Gullino ML (eds) The role of plant pathology in food safety and food security. Springer, Netherlands, Dordrecht, pp 53-71

Fader M, Gerten D, Krause M, Lucht W, Cramer W (2013) Spatial decoupling of agricultural production and consumption: quantifying dependences of countries on food imports due to domestic land and water constraints. Environ Res Lett 8:014046

Fenner F, Henderson DA, Arita I, Jezek Z, Ladnyi I (1988) Smallpox and its eradication. World Health Organization, Geneva

Ferrinho P, Omar MC, Fernandes M, Blaise P, Bugalho A, Lerberghe W (2004) Pilfering for survival: how health workers use access to drugs as a coping strategy. Hum Resour Health 2:4

Fidler DP (2010) Negotiating equitable access to influenza vaccines: global health diplomacy and the controversies surrounding avian influenza H5N1 and pandemic influenza H1N1. PLoS Med $7: \mathrm{e} 1000247$

Field H, de Jong C, Melville D et al (2011) Hendra virus infection dynamics in Australian fruit bats. PLoS ONE 6:e28678

Fotso J (2006) Child health inequities in developing countries: differences across urban and rural areas. Int J Equity Health 5:9

Friant S, Paige SB, Goldberg TL (2015) Drivers of bushmeat hunting and perceptions of zoonoses in Nigerian hunting communities. PLoS Negl Trop Dis 9:e0003792 
Frost WH (1920) Statistics of influenza morbidity: with special reference to certain factors in case incidence and case fatality. Public Health Reports (1896-1970), pp 584-597

Fung ICH, Cairncross S (2006) Effectiveness of handwashing in preventing SARS: a review. Tropical Med Int Health 11:1749-1758

Gaitonde R, Oxman AD, Okebukola PO, Rada G (2016) Interventions to reduce corruption in the health sector. Cochrane Database of Systematic Reviews (Online) CD008856

Galiani S, Gertler PJ, Orsola-Vidal A (2012) Promoting handwashing behavior in Peru: the effect of large-scale mass-media and community level interventions. World Bank Policy Research Working Paper

García-Prado A, Chawla M (2006) The impact of hospital management reforms on absenteeism in Costa Rica. Health Policy Plan 21:91-100

Girard MP, Tam JS, Assossou OM, Kieny MP (2010) The 2009 A (H1N1) influenza virus pandemic: a review. Vaccine 28:4895-4902

Gondwe TN, Wollny CBA (2007) Local chicken production system in Malawi: household flock structure, dynamics, management and health. Trop Anim Health Prod 39:103-113

Gong M, Lempert R, Parker A et al (2017) Testing the scenario hypothesis: an experimental comparison of scenarios and forecasts for decision support in a complex decision environment. Environ Model Softw 91:135-155

Gray-Molina G, de Rada E, Yañez E (2001) Does voice matter? Participation and controlling corruption in Bolivian hospitals. Diagnosis Corruption Fraud in Latin America's Public Hospitals

Guerrero JM, Blaabjerg F, Zhelev T et al (2010) Distributed generation: toward a new energy paradigm. IEEE Ind Electron Mag 4:52-64

Gurley ES, Montgomery JM, Hossain MJ et al (2007) Person-to-person transmission of Nipah virus in a Bangladeshi community. Emerg Infect Dis 13:1031-1037

Hadley MB, Blum LS, Mujaddid S et al (1982) Why Bangladeshi nurses avoid 'nursing': social and structural factors on hospital wards in Bangladesh. Soc Sci Med 2007(64):1166-1177

Halpin K, Hyatt AD, Fogarty R et al (2011) Pteropid bats are confirmed as the reservoir hosts of henipaviruses: a comprehensive experimental study of virus transmission. Am J Trop Med Hyg 85:946-951

Hays JN (2005) Epidemics and pandemics: their impacts on human history. Abc-clio

Hayward MLA, Shepherd DA, Griffin D (2006) A hubris theory of entrepreneurship. Manag Sci $52: 160-172$

Hegde ST, Sazzad HM, Hossain MJ et al (2016) Investigating rare risk factors for Nipah virus in Bangladesh: 2001-2012. EcoHealth 13:720-728

Holsti OR (1972) Time, alternatives, and communications: the 1914 and Cuban missile crises. In: Hermann CF (ed) International crisis: insight from behavioral research. Free Press, New York, pp 58-82

Hoornweg D, Pope K (2017) Population predictions for the world's largest cities in the 21st century. Environ Urban 29:195-216

Hossain MJ, Gurley ES, Montgomery JM et al (2008) Clinical presentation of Nipah virus infection in Bangladesh. Clin Infect Dis 46:977-984

Hsu VP, Hossain MJ, Parashar UD et al (2004) Nipah virus encephalitis reemergence, Bangladesh. Emerg Infect Dis 10:2082-2087

Humphreys M, Weinstein JM (2009) Field experiments and the political economy of development. Annu Rev Polit Sci 12:367-378

Jackson C, Vynnycky E, Hawker J, Olowokure B, Mangtani P (2013) School closures and influenza: systematic review of epidemiological studies. BMJ Open 3

Kaluza P, Kölzsch A, Gastner MT, Blasius B (2010) The complex network of global cargo ship movements. J R Soc Interface 7:1093-1103

Keinan G (1987) Decision making under stress: scanning of alternatives under controllable and uncontrollable threats. J Pers Soc Psychol 52:639 
Kelly H, Peck HA, Laurie KL, Wu P, Nishiura H, Cowling BJ (2011) The age-specific cumulative incidence of infection with pandemic influenza H1N1 2009 was similar in various countries prior to vaccination. PLoS ONE 6:e21828

Killingsworth JR, Hossain N, Hedrick-Wong Y, Thomas SD, Rahman A, Begum T (1999) Unofficial fees in Bangladesh: price, equity and institutional issues. Health Policy Plan $14: 152-163$

Kombe WJ (2005) Land use dynamics in peri-urban areas and their implications on the urban growth and form: the case of Dar es Salaam, Tanzania. Habitat Int 29:113-135

Krausmann F, Erb K, Gingrich S et al (2013) Global human appropriation of net primary production doubled in the 20th century. Proc Natl Acad Sci 110:10324-10329

Langford R, Lunn P, Panter-Brick C (2011) Hand-washing, subclinical infections, and growth: a longitudinal evaluation of an intervention in Nepali slums. Am J Hum Biol: Off J Hum Biol Counc 23:621-629

Lau JT, Yang X, Tsui H, Kim JH (2003) Monitoring community responses to the SARS epidemic in Hong Kong: from day 10 to day 62. J Epidemiol Community Health 57:864-870

Lewis M, Gelander G (2009) Governance in health care delivery: raising performance. The World Bank, Washington DC

Lilliston B, Ranallo A (2012) Grain reserves and the food price crisis. Selected Writings from 2008-2012

Luby SP (2013) The pandemic potential of Nipah virus. Antivir Res 100:38-43

Luby SP, Rahman M, Hossain MJ et al (2006) Foodborne transmission of Nipah virus, Bangladesh. Emerg Infect Dis 12:1888-1894

Luby S, Hossain J, Gurley E et al (2009) Recurrent zoonotic transmission of Nipah virus into humans, Bangladesh, 2001-2007. Emerg Infect Dis 15:1229-1235

Mack TM (1972) Smallpox in Europe, 1950-1971. J Infect Dis 125:161-169

Manabe T, Hanh TT, Lam DM et al (2012) Knowledge, attitudes, practices and emotional reactions among residents of avian influenza (H5N1) hit communities in Vietnam. PLoS ONE 7:e47560

Massoud MA, Tarhini A, Nasr JA (2009) Decentralized approaches to wastewater treatment and management: applicability in developing countries. J Environ Manag 90:652-659

McCoy D, Bennett S, Witter S et al (2008) Salaries and incomes of health workers in sub-Saharan Africa. Lancet 371:675-681

McCullough D (2007) Johnstown Flood. Simon and Schuster

McIntosh AC (2003) Asian water supplies reaching the urban poor. Asian Development Bank and International Water Association

Middleton DJ, Morrissy CJ, van der Heide BM et al (2007) Experimental Nipah virus infection in pteropid bats (Pteropus poliocephalus). J Comp Pathol 136:266-272

Migdal JS (1988) Strong societies and weak states: state-society relations and state capabilities in the Third World. Princeton University Press

Molina MJ, Rowland FS (1974) Stratospheric sink for chlorofluoromethanes: chlorine atom-catalysed destruction of ozone. Nature 249:810

Moore C (1990) Unpredictability and undecidability in dynamical systems. Phys Rev Lett 64:2354-2357

Morse SS, Mazet JA, Woolhouse M et al (2012) Prediction and prevention of the next pandemic zoonosis. Lancet 380:1956-1965

Nahar N, Uddin M, Sarkar RA et al (2013) Exploring pig raising in Bangladesh: implications for public health interventions. Vet Ital 49:7-17

Narae C (2014) Metro Manila through the gentrification lens: disparities in urban planning and displacement risks. Urban Stud 53:577-592

Newman PA, Oman LD, Douglass AR et al (2009) What would have happened to the ozone layer if chlorofluorocarbons (CFCs) had not been regulated? Atmos Chem Phys 9:2113-2128

Nishiura H (2010) Case fatality ratio of pandemic influenza. Lancet Infect Dis 10:443-444

Nixon R (2011) Slow violence and the environmentalism of the poor. Harvard University Press

Nordberg C (2008) Corruption in the health sector. CMI, Bergen 
Nowak R (1994) Walker's bats of the world. Johns Hopkins University Press, Baltimore

Østby G (2008) Inequalities, the political environment and civil conflict: evidence from 55 developing countries. In: Stewart F (ed) Horizontal inequalities and conflict: understanding group violence in multiethnic societies. Palgrave Macmillan UK, London, pp 136-159

Parlak E, Ertürk A, Koşan Z, Parlak M, Özkurt Z (2015) A nosocomial outbreak of Crimean-Congo hemorrhagic fever. J Microbiol Infect Dis 5

Partridge J, Kieny MP (2010) World Health Organization H1N1 influenza vaccine Task Force. Global production of seasonal and pandemic (H1N1) influenza vaccines in 2009-2010 and comparison with previous estimates and global action plan targets. Vaccine 28:4709-4712

Paul M, Baritaux V, Wongnarkpet S et al (2013) Practices associated with highly pathogenic avian influenza spread in traditional poultry marketing chains: social and economic perspectives. Acta Trop 126:43-53

Perrow C (1999) Organizing to reduce the vulnerabilities of complexity. J Conting Crisis Manag 7:150-155

Rajakaruna SJ, Liu WB, Ding YB, Cao GW (2017) Strategy and technology to prevent hospital-acquired infections: lessons from SARS, Ebola, and MERS in Asia and West Africa. Mil Med Res 4:32

Rimi NA, Sultana R, Luby SP et al (2014) Infrastructure and contamination of the physical environment in three Bangladeshi hospitals: putting infection control into context. PLoS ONE 9:e89085

Rimi NA, Sultana R, Ishtiak-Ahmed K et al (2016) Understanding the failure of a behavior change intervention to reduce risk behaviors for avian influenza transmission among backyard poultry raisers in rural Bangladesh: a focused ethnography. BMC Public Health 16:858

Rimi NA, Sultana R, Muhsina M et al (2017) Biosecurity conditions in small commercial chicken farms, Bangladesh 2011-2012. EcoHealth 14:244-258

Roenen C, Ferrinho P, Van Dormael M, Conceicao MC, Van Lerberghe W (1997) How African doctors make ends meet: an exploration. Trop Med Int Health 2:127-135

Rubin GJ, Amlot R, Page L, Wessely S (2009) Public perceptions, anxiety, and behaviour change in relation to the swine flu outbreak: cross sectional telephone survey. BMJ (Clin Res ed) 339: b2651

Segerfeldt F (2005) Water for sale: how business and the market can resolve the world's water crisis. Cato Institute

Shears P, O'Dempsey TJD (2015) Ebola virus disease in Africa: epidemiology and nosocomial transmission. J Hosp Infect 90:1-9

Slovic P, Finucane ML, Peters E, MacGregor DG (2004) Risk as analysis and risk as feelings: some thoughts about affect, reason, risk, and rationality. Risk Anal 24:311-322

Stanton BF, Clemens JD (1987) An educational intervention for altering water-sanitation behaviors to reduce childhood diarrhea in urban Bangladesh. II. A randomized trial to assess the impact of the intervention on hygienic behaviors and rates of diarrhea. Am J Epidemiol 125:292-301

Starcke K, Wolf OT, Markowitsch HJ, Brand M (2008) Anticipatory stress influences decision making under explicit risk conditions. Behav Neurosci 122:1352

Stewart F, Holdstock D, Jarquin A (2002) Root causes of violent conflict in developing countries commentary. Conflict—from causes to prevention? BMJ (Clinical research ed) 324:342-345

Strange RN, Scott PR (2005) Plant disease: a threat to global food security. Annu Rev Phytopathol 43:83-116

Sultana R, Rimi NA, Azad S et al (2012) Bangladeshi backyard poultry raisers' perceptions and practices related to zoonotic transmission of avian influenza. J Infect Dev Ctries 6:156-165

Suweis S, Carr JA, Maritan A, Rinaldo A, D'Odorico P (2015) Resilience and reactivity of global food security. Proc Natl Acad Sci 112:6902-6907

Sverdlik A (2011) Ill-health and poverty: a literature review on health in informal settlements. Environ Urban 23:123-155 
Talaat M, Afifi S, Dueger E et al (2011) Effects of hand hygiene campaigns on incidence of laboratory-confirmed influenza and absenteeism in schoolchildren, Cairo, Egypt. Emerg Infect Dis 17:619-625

Taleb NN (2007) The black swan: the impact of the highly improbable. Random House

Tatem AJ, Hay SI, Rogers DJ (2006) Global traffic and disease vector dispersal. Proc Natl Acad Sci 103:6242-6247

Tetlock PE (2017) Expert political judgment: how good is it? How can we know? Princeton University Press

Thappa D, Gupta DN (2014) The growing poison of corruption in health systems: how deep is the rot? Int J Adv Med Health Res 1:1-2

Torngren G, Montgomery H (2004) Worse than chance? Performance and confidence among professionals and laypeople in the stock market. J Behav Financ 5:148-153

Trutnevyte E, Guivarch C, Lempert R, Strachan N (2016) Reinvigorating the scenario technique to expand uncertainty consideration. Clim Change 135:373-379

Tversky A, Kahneman D (1973) Availability: a heuristic for judging frequency and probability. Cogn Psychol 5:207-232

UN Habitat (2015) UN ESCAP. The State of Asian and Pacific Cities 2015. UN-Habitat

United Nations (2016) The World's Cities in 2016 - Data Booklet (ST/ESA/ SER.A/392)

Wacharapluesadee S, Boongird K, Wanghongsa S et al (2010) A longitudinal study of the prevalence of Nipah virus in Pteropus lylei bats in Thailand: evidence for seasonal preference in disease transmission. Vector Borne Zoonotic Dis 10:183-190

Weiss RA, McMichael AJ (2004) Social and environmental risk factors in the emergence of infectious diseases. Nat Med 10:S70-S76

Wolfe ND, Dunavan CP, Diamond J (2007) Origins of major human infectious diseases. Nature 447:279-283

World Bank (2018) World development indicators. World Bank, Washington DC

World Health Organization (2004) Practical guidelines for infection control in health care facilities. WHO Regional Office for the Western Pacific, Manila

World Health Organization (2015) Unicef. Water, sanitation and hygiene in health care facilities: status in low and middle income countries and way forward. World Health Organization, Geneva, Report No.: 9241508477

World Health Organization (2017) 2017 Annual review of diseases prioritized under the Research and Development Blueprint. World Health Organization, Geneva

Zaman S (1982) Poverty and violence, frustration and inventiveness: hospital ward life in Bangladesh. Soc Sci Med 2004(59):2025-2036

Zebardast E (2006) Marginalization of the urban poor and the expansion of the spontaneous settlements on the Tehran metropolitan fringe. Cities 23:439-454

Zezza A, Tasciotti L (2010) Urban agriculture, poverty, and food security: Empirical evidence from a sample of developing countries. Food Policy 35:265-273 